\title{
LEGISLAÇÃO SIMBÓLICA E DIREITOS FUNDAMENTAIS: A INEFICÁCIA DO CRIME DE EXPLORAÇÃO DO TRABALHO ESCRAVO NA LEGISLAÇÃO BRASILEIRA
}

\author{
SYMBOLIC LAW AND FUNDAMENTAL RIGHTS: A FAILURE OF WORK \\ EXPLORATION CRIME IN BRAZILIAN SLAVE LAW.
}

\author{
${ }^{1}$ Marcio Cristiano De Gois \\ ${ }^{2}$ Matheus Felipe De Castro
}

\section{RESUMO}

$\mathrm{O}$ artigo tem por tema analisar o crime como ferramenta de combate à escravidão. $\mathrm{O}$ problema da pesquisa concentra-se no efeito simbólico trazido pela lei 10.803/03. A hipótese inicial de trabalho é que o crime encontra um espaço heterônomo de conceituação extremamente complexo. Justifica-se a temática em virtude de que ainda milhares de pessoas são submetidas ao trabalho escravo no Brasil, violando direitos fundamentais. O Método utilizado é o dedutivo e parte de referenciais teóricos marxistas e da criminologia crítica em três partes abordando, escravidão, o crime, a legislação simbólica e criminologia, representando uma pesquisa em desenvolvimento com resultados parciais

Palavras-chave: Escravidão, Direitos fundamentais, Legislação simbólica

\begin{abstract}
The article is subject to analyze crime as slavery fighting tool. The problem of research focuses on the symbolic effect brought by Law 10,803/2003. The initial hypothesis is that crime finds a heteronomous space extremely complex concept. Justified the issue because of still thousands of people are subjected to slave labor in Brazil, violating fundamental rights. The method used is the deductive and part of Marxist theoretical frameworks and critical criminology in three parts addressing, slavery, crime, criminology and symbolic legislation, representing a research development with partial results
\end{abstract}

Keywords: Slavery, Fundamental rights, Symbolic legislation

\footnotetext{
${ }^{1}$ Mestrando em Direito na Universidade do Oeste de Santa Catarina - UNOESC, Joaçaba - SC (Brasil). Professor da Universidade Paranaense - UNIPAR, Umuarama - PR (Brasil). E-mail: degois@ hotmail.com

${ }^{2}$ Doutor em Direito pela Universidade Federal de Santa Catarina - UFSC, Florianópolis - SC (Brasil). Professor da Universidade do Oeste de Santa Catarina - UNOESC, Joaçaba - SC (Brasil).

E-mail: matheusfelipedecastro@gmail.com
} 


\section{INTRODUÇÃO}

O presente artigo tem por tema analisar o Artigo 149 do Código Penal como instrumento de combate da escravidão contemporânea, dentro desta situação é preciso reproduzir o cenário da escravidão contemporânea existente no Brasil, bem como os motivos que levaram a alteração do tipo penal dentro dessa realidade.

O problema da pesquisa se concentra na ampliação dos modelos de comportamentos proibidos descritos no art. 149, do Código Penal, após o advento da Lei n. 10.803/2003, tornando-o permeável a dúvidas que enfraqueceram o caráter necessariamente fechado do tipo, o que pode levar, por um lado, a sua inaplicabilidade (legislação penal com caráter meramente simbólico) e, por outro, à sua aplicação seletiva, na medida em que a sua permeabilidade interpretativa pode induzir até mesmo a aplicações analógicas.

A utilização da lei simbólica possui como principal exemplo histórico a lei Feijó de 1831, a qual foi utilizada como -álibill político durante a escravidão colonial frente à pressão inglesa. Quase duzentos anos depois, o legislador brasileiro para combater e controlar a pressão externa no combate à escravidão contemporânea utiliza o mesmo recurso simbólico de uma -Lei para inglês ver. Contudo, dentro desta simbologia, surgem dois opostos, o primeiro se manifesta pela ineficácia total e o segundo pela supereficácia seletiva com o emprego da analogia.

A hipótese inicial de trabalho é que o crime encontra um espaço heterônomo de conceituação na sociedade, razão pela qual o direito do trabalho e o direito penal acabam pregando conceitos diversos sobre o que seria o trabalho escravo contemporâneo gerando confusão conceitual e dificuldades interpretativas insuperáveis.

Justifica-se a temática na medida em que o trabalho escravo ainda é uma realidade nacional e o país assumiu obrigações internacionais para implementar medida positivas e eficazes para o seu combate. Outrossim, a Organização Internacional do Trabalho (OIT) declarou que no Brasil existem milhares de pessoas submetidas ao trabalho escravo, portanto, resta imprescindível realizar uma pesquisa voltada para a tutela dos direitos fundamentais, em especial do direito de liberdade, que fujam da visão simplista do direito penal como instrumento capaz de resolver problemas sociais através das criminalizações primária e secundária. 
Objetiva-se, com o trabalho, colaborar para o fornecimento de elementos à pesquisa que tenham por objeto o estudo desse importante direito fundamental, o qual merece destaque diante de uma legislação simbólica que pode levar aos extremos da ineficácia ou de sua aplicação analógica gerando supereficácia.

O Trabalho procura por meio de releituras dos referenciais teóricos marxistas e da criminologia crítica desenvolver o trabalho a partir do método dedutivo, partindo de uma premissa geral (maior) para uma específica (menor), dividindo o mesmo em três partes.

O primeiro capítulo busca estudar o cenário da escravidão contemporânea, desta maneira procura-se separar os tipos de escravidão existentes bem como os fatores essenciais para a sua definição.

O segundo capítulo procura apresentar os problemas trazidos com a Lei $\mathrm{n}^{\mathbf{o}}$. 10.803/2003, bem como as dificuldades em apresentar definições fechadas as expressões trazidas pela norma, além de apurar a existência de eventuais abolitio criminis.

O Terceiro Capítulo tem a função de apresentar a caracterísitica simbólica contida na norma, apresentando a comparação com a Lei Feijó de 1831 que foi responsável por cumprir a função diplomática, contudo, no Brasil revelava-se ser uma lei simbólica e ineficaz.

O presente trabalho não procura apresentar conclusões peremptórias, haja vista que representa um estado de pesquisa em desenvolvimento com resultados parciais.

\section{O CENÁRIO DA ESCRAVIDÃO CONTEMPORÂNEA}

Quando se aborda o tema da escravidão o imaginário popular encontra nas fazendas coloniais, na população negra africana acorrentada, na chibata o modelo de escravidão. Contudo, a escravidão ao longo do tempo e espaço não é homogênea, neste sentido destaca (VIANA, 2006) que ao longo da história ela se manifesta de forma e objetivos desiguais.

GORENDER (2010) destaca que dentro das formas de escravidão é possível identificar que o atributo primário vinculado à ideia de propriedade nem sempre se transmitiu pelos critérios da perpetuidade e da hereditariedade. Segundo o autor, existem formas de escravidão em que era possível identificar a cessação da exploração após um prazo determinado.

Outras formas desta desigualdade da exploração da escravidão, segundo GORENDER (2010) encontra-se na Ásia em que o indivíduo nunca se converte em proprietário, mas em mero 
possuidor. Já no direito romano é possível ver a característica, por exemplo, da transmissão hereditária. Portanto, a escravidão não pode ser classificada com uma única espécie, mas sim como um gênero que possui diversas modalidades ao longo do tempo e espaço.

No momento atual, somando as características apresentas pela OIT, bem como pelas expressões contidas no tipo penal descrito no artigo 149 do Código Penal Brasileiro é possível identificar, pelos menos cinco categorias que conceituam o núcleo da escravidão contemporânea.

Segundo (VIANA, 2006) a primeira categoria se relaciona a própria falta explícita de liberdade, dentro desta modalidade não se torna necessária a ameaça física, basta a simples existência de uma dívida crescente e impagável para que possa ser suficiente para tolher sua liberdade.

Similar a essa primeira categoria encontrava-se a figura do trabalho escravo no momento pós-indígena, denominados como -engajados\| ou -Quitadores\| (WILLIAMS, 2012) os engajados e quitadores precisavam trabalhar em trocas das despesas de transporte.

Verifica-se a presença desta categoria em diversos setores da economia nacional, citase, por exemplo, os vários trabalhadores que são deslocados de seu -habitatl natural na busca de oportunidades que necessitam ser quitadas. Durante esse longo período grande parte de suas liberdades ambulatoriais são restringidas.

A segunda categoria se liga com o trabalho exaustivo, assédio moral e situações análogas da escravidão, ao passo que a terceira categoria se liga ao salário (VIANA, 2006). Nestas categorias o escravo contemporâneo muito se aproxima a figura do trabalhador inglês explorado durante a revolução industrial, como destaca MARX (1998), percebe-se um trabalhador que era formalmente -livrell, mas encontra-se materialmente escravizado pelo salário e pelas péssimas condições de trabalho.

A quarta categoria também se aproxima ao trabalhador industrial, bem como ao trabalhador colonial. Esta categoria trabalha com as condições degradantes da saúde do trabalhador e nas péssimas condições no fornecimento da moradia, da alimentação. (VIANA, 2006).

Existe uma outra categoria que não é listada por VIANA(2006), trata-se da escravidão decorrente do tráfico de pessoas, bem como a escravidão sexual. Destaca ROCHA (2013) que o tráfico de pessoas é a terceira modalidade de crime transnacional mais lucrativa do mundo.

Reconhecido, portanto, que na contemporaneidade existem diferentes tipos de escravidão, com a finalidade de delimitar o estudo, bem como a relação envolve a escravidão 
e o Capitalismo, o trabalho cinge-se em analisar as cinco categorias apresentadas por VIANA (2006).

Desta maneira, ao contrário do que vivido na história, o escravo contemporâneo não pertence a uma categoria isolada ao ponto de se tornar uma -raçall determinada, como foi o caso do índio e do negro. Desta maneira a questão não se encontra na diversidade de uma raça no plano biológico, como destaca Claude Lévi-Strauss (1960), mas também na desigualdade de condições de vida das diversas culturas.

A questão que liga todas as categorias estudadas à escravidão é o excesso do lucro e a teoria econômica da mais valia de Karl Marx. Desta maneira, o capitalismo, que em tempos passados foi conceituado como o maior abolicionista da escravidão colonial, neste momento revela-se o principal -Senhor do Engenholl da escravidão contemporânea.

Assim, a busca pelo lucro a qualquer custo revela a existência de modelos de exploração da mão de obra não adeptos ao discurso dos direitos fundamentais, copiando modelos capitalistas da Inglaterra dos séculos XVII e XVIII.

Desde já, explica-se que o escravo, quando visto como propriedade era considerado um -fardoll ao dono, tratava-se de um bem que não promovia tanto lucro, em virtude de que gerava muitas despesas e não consumia os bens produzidos, portanto, incompatível com o modelo capitalista.

Contudo, o -Escravo Assalariado\| ${ }^{1}$, a nova espécie que nasceu com o capitalismo, gera lucro, seu custo é muito baixo e serve para promover a vantagem econômica do capitalista que vê na exploração de mão de obra barata a potencialidade de concorrência e de acúmulo de capital, similar ao modo de exploração que estava submetido o trabalhador inglês durante o século XVII e XVIII.

\footnotetext{
${ }^{1}$ A expressão "Escravo Assalariado" é empregada para diferenciar os modelos e tipos de escravos existentes na atualidade. Entende-se por "Escravo Assalariado" aquele que se submete a condições de trabalho similar aquelas vividas pelo trabalhador Inglês, formalmente livre e materialmente escravizado. Toda a relação se adere ao modo de exploração da mão de obra pela teoria econômica da mais valia de Karl Marx (1998), da política do lucro a qualquer custo.
} 
Como destaca (MARX, 1998) a presença da escravidão e servidão existem e desaparecem a partir da índole da produção. Assim, não se trata da justiça e da fraternidade os elementos chaves para o fim da escravidão, mas sim a estrutura econômica e a forma de exploração do trabalho ser compatível ou não. -[...]As suas causas encontram-se: na estrutura econômica, no modo de produção e da troca, que preside à distribuição das riquezas e, por conseguinte, à formação das classes e à hierarquia. [...] (MARX, 1998, p. 18-9)

Destaca-se que o movimento que retirou o trabalhador escravo e o tornou livre é uma falácia, um -slogan\| como trabalha Lenin em seu discurso de -Como iludir o povo com os slogans de liberdade e igualdadel, neste sentido destaca que:

\begin{abstract}
A "liberdade e igualdade" no sistema burguês (isto é, enquanto se mantiverem a propriedade privada das terras e dos meios de produção) e na democracia burguesa, serão meramente formais, o que significa, na realidade, escravatura salarial para os trabalhadores (que são, formalmente, livres, gozando, formalmente, de direitos iguais), todo o poder para o capital, e opressão do trabalho pelo capital. Este é o $\mathrm{ABC}$ do Socialismo, "eruditos -cavalheiros - e vocês esqueceram este ABC. (LENIN, 1980, p. 8-9)
\end{abstract}

Como observa LENIN (1980), a liberdade vira o símbolo ilusório do capitalismo abolicionista, quando na realidade, com os -slogans\| forma-se uma - cortina de fumaçall ao surgimento de uma outra categoria de escravidão, o -Escravo Assalariadoll.

Neste sentido já destacava (MARX, 1998, p. 19) que -0 trabalhador livre, podendo de direito dispor da sua pessoa viu-se obrigado de fato a dispor dela para viver, não tendo outra coisa que vender. Desde então foi condenado ao papel de assalariado durante toda a sua vidall.

Durante a contemporaneidade é possível identificar a presença de trabalho -escravo assalariadoll, semi-livre, sendo possível identificar que muitos dos trabalhadores encontram-se cerceados de suas liberdades, no presente caso pelo salário, como destaca (MARX, 1998, p. 20)

\footnotetext{
O sistema de salário, substituindo as diversas formas de trabalhos forçados, aliviou o capitalista da manutenção dos produtores. O escravo tinha assegurada a sua alimentação quotidiana, quer fosse obrigado a trabalhar quer não; o assalariado não pode comprar a sua senão com a condição de que o capitalista necessite de seu trabalho; (MARX, 1998, p. 20)
}

Verifica-se na atualidade que em decorrência do desemprego e demais questões básicas como moradia, saúde e alimentação da população, grande parcela dela sofre com uma exploração da mão de obra similar àquela praticada na Inglaterra durante a revolução industrial. 
No modelo atual, o escravo assalariado representa uma das categorias da escravidão contemporânea, pois o recebimento de um salário não é instrumento suficiente para atribuir a este trabalhador a qualidade de ser considerado um homem livre. A liberdade formal é utilizada como o -Sloganl que justifica a realidade do sistema conflituoso e permanente de lutas de classes e de um jogo de poder.

Desta maneira, é possível concluir que o capitalismo foi responsável pelo rompimento da escravidão colonial, haja vista que o modelo escravocrata colonial era incompatível com o modelo proposto pelo capitalismo inglês na formação de um mercado de consumidores.

Durante a industrialização inglesa inicial, o processo de implementação do salário foi responsável por transformar o trabalhador num homem formalmente livre, contudo, analisando as condições de trabalho e o valor do salário percebe-se um trabalhador escravizado, similar ao escravo contemporâneo.

Desta maneira, o capitalismo foi o abolicionista de um modelo escravocrata baseado no escravo como um direito real de propriedade e o criador de um escravo formalmente livre, o -escravo assalariadoll.

O trabalhador inglês que foi explorado durante a revolução industrial representa o modelo mais próximo do -escravo assalariadoll, revelando que a questão central não é abolicionista, mas sim, classificatória, promovendo o reenquadramento do problema em outra espécie de escravidão, altamente lucrativa pelo tempo de trabalho não remunerado a serviço do empregador.

\begin{abstract}
A exploração corre por causa da diferença entre o valor das mercadorias que um trabalhador produz e o valor da força de trabalhador mercantilizada do trabalhador (a capacidade de trabalhar durante um tempo específico em troca de salários) o que significa que a fonte oculta do lucro capitalista é o tempo de trabalho não remunerado. (BOUCHER (2015, p. 76)
\end{abstract}

Dentro deste cenário escravocrata capitalista surgem, por obrigações internacionais, a criação de mecanismos de combate à escravidão no Brasil. No presente artigo será abordado o crime descrito no Art. 149 do Código Penal.

\title{
3 O CRIME DE EXPLORAÇÃO DO TRABALHO ESCRAVO.
}

A relação do crime e escravidão sempre foram elementos importantes ao longo da história. A primeira situação que afastou o escravo da situação de —coisall foi justamente o 
homicídio, haja vista que indiretamente pela punição reconhecia-se um sujeito de deveres. GORENDER (2010, p. 95) diz que -0 primeiro ato humano do escravo é o crime, desde o atentado contra o senhor à fuga do cativeiro. Em Contrapartida, ao reconhecer a responsabilidade penal dos escravos a sociedade escravista os reconhecia como homens; além de incluí-los no direito das coisas, submetia-os a legislação penal. [...]

O escravo, ao praticar o crime, ao violar direitos de outrem, foi reconhecido de forma precária como homem. A elevação de sua conduta não veio pela bondade, solidariedade, trabalho, mas pelo crime.

Acerca do crime de exploração de trabalho escravo definido no código penal, inúmeros são os seus questionamentos, O problema do tipo penal encontrado na norma do artigo $149^{2}$ do Código Penal já está no próprio legislador brasileiro, o qual, como sempre faz legisla sempre em cima de casos concretos. -É mais fácil e mais barato para o Poder Público editar novas leis penais e aumentar as respectivas sanções, do que adotar políticas publicas ou tentar criar novos empregos (BITENCOURT, 2007, p. 387)\|

As expressões trazidas pelo tipo penal descritos na lei como: -trabalhos forçadosl; - Jornada exaustivall - condições degradantes de trabalholl representam expressões muito vagas. A interpretação destes elementos dentro do ordenamento jurídico não se manifesta de maneira uniforme entre as ciências do direito, especialmente no conflito entre Direito Penal e Direito do Trabalho, causando insegurança em sua aplicação.

\footnotetext{
${ }^{2}$ Art. 149. Reduzir alguém a condição análoga à de escravo, quer submetendo-o a trabalhos forçados ou a jornada exaustiva, quer sujeitando-o a condições degradantes de trabalho, quer restringindo, por qualquer meio, sua locomoção em razão de dívida contraída com o empregador ou preposto: Pena - reclusão, de dois a oito anos, e multa, além da pena correspondente à violência $\S 1^{\circ}$ Nas mesmas- penas incorre quem: I - cerceia o uso de qualquer meio de transporte por parte do trabalhador, com o fim de retê-lo no local de trabalho; II - mantém vigilância ostensiva no local de trabalho ou se apodera de documentos ou objetos pessoais do trabalhador, com o fim de retê-lo no local de trabalho. $\S 2^{\circ}$ A pena é aumentada de metade, se o crime é cometido: I - contra criança ou adolescente; II - por motivo de preconceito de raça, cor, etnia, religião ou origem
} 
Observa BITENCOURT (2007), a alteração promovida na Lei 10.803/2003 foi responsável pela restrição e limitação no alcance do tipo penal. Desta maneira, o que antes da reforma era um crime de forma livre passou com a nova lei a ser um crime especial. As expressões trazidas -Empregador\| -Trabalhador\|-Local de Trabalhol, trazem meios e formas de execução específicos, além da própria definição do sujeito passivo, remetendo a um crime especial, voltado a uma relação de trabalho, o que marca sua especialidade.

Dentro da estrutura do tipo penal, verifica-se a presença de -falhas\| e-equívocos da legislação tornam o crime um instrumento formalmente legal, contudo, pela sua definição totalmente ineficaz no combate ao trabalho escravo. Desta maneira, fomenta-se a discussão POULANTZAS (2010) se a presença destas falhas foram inseridas por descuido, erro e imprudência ou se o objetivo do legislador realmente era criar uma norma penal aterrorizante, nominativa, simbólica e ineficaz.

Como já visto a Convenção n ${ }^{\circ} 29$ de 1930 da Organização Internacional do Trabalho estabelece que -. Para fins desta Convenção, a expressão trabalho forçado ou obrigatório compreenderá todo trabalho ou serviço exigido de uma pessoa sob a ameaça de sanção e para o qual não se tenha oferecido espontaneamente.

Além disso, a mesma Convenção dispõe em seu artigo $25^{3}$ que a imposição ilegal de trabalho forçado será passível de sanções penais e estabelece a obrigação que todo o Estado membro deve assegurar que as sanções impostas por lei sejam adequadas e rigorosamente cumpridas.

A respectiva convenção foi assinada pelo Brasil durante a década de cinquenta e nesta época o Código Penal de 1940 já trazia a redação e a tipificação do crime de exploração de trabalho escravo como sendo -Reduzir alguém a condição análoga à de escravoll. Contudo, a falta da aplicação da norma penal, o desejo punitivo e o efeito midiático foram responsáveis para a ampliação do tipo penal, marcado pela indefinição do que é uma condição análoga de escravo.

Destaca BITENCOURT (2007, p. 387) que o efeito midiático da reforma do crime esteve vinculado a uma reportagem de 14 de dezembro de 2002, a notícia do Correio Braziliense

\footnotetext{
3 -Artigo 25 A imposição ilegal de trabalho forçado ou obrigatório será passível de sanções penais e todo Paísmembro que ratificar esta Convenção terá a obrigação de assegurar que as sanções impostas por lei sejam realmente adequadas e rigorosamente cumpridas.
} 
destacava que o Ministério do Trabalho e Emprego libertou nos últimos anos cerca de trinta mil trabalhadores do regime da escravidão, contudo, a notícia demonstrava a ineficácia da libertação, haja vista que dos trinta mil libertos, aproximadamente doze mil trabalhadores teriam voltado a condição de escravos pela ausência de oportunidades. A reportagem ainda apontou em $40 \%$ o índice de reincidência do crime em alguns estados.

Diante da pressão política existente após o reconhecimento da escravidão no plano internacional, bem como pelo efeito midiático associado à impunidade e reincidência, apresentou-se como uma solução rápida e barata a lei nº $10.803 / 2003$.

Pela análise descritiva do tipo penal é possível identificar a presença de expressões que colidem com a política capitalista do lucro a qualquer custo, quais sejam: -Jornada exaustivall -condições degradantes de trabalho\| -retê-lo no local de trabalhol -vigilância no local de trabalholl-documentos ou objetos pessoais do trabalhadorll.

Para Bitencourt (2007), o modelo proposto pela lei em destaque acabou gerando um resultado inverso ao que pretendia o legislador. Desta maneira com o agravamento das sanções, ampliação das condutas, bem como dos meios e formas de infringir a lei penal, - [...]o legislador restringiu o alcance do tipo penal anterior: de crime de forma livre, passou a ser especial [...] desta maneira, segundo o autor o sujeito passivo que antes poderia ser qualquer pessoa, com a nova redação é somente o empregado ou trabalhador. Acerca do meio e forma de execução o que antes era de forma livre, com a nova redação possuía meios e formas próprios. Com isso, a norma nova acabou criando casos de abolitio criminis.

As expressões trazidas são muito imprecisas e contraditórias, colidindo com conceitos não unânimes do Direito Penal e do Direito do Trabalho, gerando a insegurança que marca tanto a ineficácia quanto a supereficácia seletiva com o emprego de analogias, tentando definir o complexo como simples.

Percebe-se no direito do trabalho que inúmeras decisões utilizam as expressões que tipificariam o crime de maneira natural e reiterada, sendo constante e comum que o juiz do trabalho afirme que o trabalhador estava submetido a uma -jornada exaustivall. Nestas situações teria ocorrido a materialização do crime?

A priori, não existe unanimidade na doutrina, na legislação e no poder judiciário sobre as expressões trazidas pela norma penal. Ainda sequer existe um conceito unânime do que seria a escravidão contemporânea. 
As expressões trazidas pelo tipo penal não são identificadas de maneira sensorial pelos intérpretes do ordenamento jurídico. Desta maneira, a presença destes elementos complexos e de difícil definição dentro do tipo penal, enfraquecem a aplicação seguros, haja vista que esses -[...] elementos normativos enfraquecem a função de garantia do tipo, introduzindo certa indeterminação no conteúdo da conduta punível. (FRAGOSO, 2006, p. 165) gerando a ineficácia e ao mesmo tempo a supereficácia com o emprego da analogia.

Destaca-se que a descrição trazida dentro do Artigo $149^{4}$ do Código Penal, possui remissões e semelhanças com outros tipos penais, como é o caso do Artigo $203^{5}$ e $207^{6}$ do Código Penal o que aumentam ainda mais a problemática.

A presença de algumas expressões dentro do Art. 149 do Código Penal dificultam sua aplicação, especialmente por se tratarem de elementos totalmente contraditórios e que não estabelecem uma definição exata e unânime entre as ciências. A ausência de uma definição fechada dentro do tipo penal promove dúvidas e traz o desprestígio da norma, a qual aparentemente atende os interesses internacionais, mas indica ser totalmente incompatível com o modelo penal brasileiro, servindo como uma -lei para inglês verl, Formalmente temível, mas

materialmente inaplicável ou aplicada com analogia e excesso.

4 Art. 149 - Reduzir alguém a condição análoga à de escravo, quer submetendo-o a trabalhos forçados ou a jornada exaustiva, quer sujeitando-o a condições degradantes de trabalho, quer restringindo,_por qualquer meio. sua locomocão em razão de dívida contraída com o empregador ou preposto: Pena reclusão, de dois a oito anos, e multa, além da pena correspondente à violência. $\S 1$ o - Nas mesmas penas incorre quem: I - cerceia o uso de qualquer meio de transporte por parte do trabalhador, com o fim de retê-lo no local de trabalho: II - mantém vigilância ostensiva no local de trabalho ou se apodera de documentos ou objetos pessoais do trabalhador, com o fim de retê-lo no local de trabalho. $\S 20$ - A pena é aumentada de metade, se o crime é cometido: I - contra criança ou adolescente; II - por motivo de preconceito de raça, cor, etnia, religião ou origem. (Grifo Nosso)

5 Art. 203 - Frustrar, mediante fraude ou violência, direito assegurado pela legislação do trabalho: Pena detenção, de um ano a dois anos, e multa, além da pena correspondente à violência. $§ 1^{\circ}-\mathrm{Na}$ mesma pena incorre quem: I - obriga ou coage alguém a usar mercadorias de determinado estabelecimento. para impossibilitar o desligamento do servico em virtude de dívida: II - impede alguém de se desligar de serviços de qualquer natureza, mediante coação ou por meio da retenção de seus documentos pessoais ou contratuais. $\S 2^{\circ}$ - A pena é aumentada de um sexto a um terço se a vítima é menor de dezoito anos, idosa, gestante, indígena ou portadora de deficiência física ou mental. (Grifo Nosso)

6 Art. 207 - Aliciar trabalhadores, com o fim de levá-los de uma para outra localidade do território nacional: Pena - detenção, de um a três anos, e multa. $\S 1^{\circ}$ - Incorre na mesma pena quem recrutar trabalhadores fora da localidade de execucão do trabalho. dentro do território nacional. mediante fraude ou cobranca de qualquer quantia do trabalhador, ou, ainda, não assegurar condicões do seu retorno ao local de origem. $\$ 2^{\circ}$ - A pena é aumentada de um sexto a um terço se a vítima é menor de dezoito anos, idosa, gestante, indígena ou portadora de deficiência física ou mental. (Grifo Nosso) 


\section{LEGISLAÇÃO SIMBÓLICA E CRIMINOLOGIA}

A norma penal estudada possui características simbólicas, ou seja, dentro de sua função é possível perceber a presença da influência política na adoção de medidas de combate ao trabalho escravo. Neste sentido, Marcelo Neves (2005, p.

05) observa que -A referência simbólica a determinado instituo jurídico caracterizado por um alto grau de ineficácia normativo-jurídica serve tanto ao encobrimento dessa realidade e mesmo à manipulação política para usos contrários à concretização e efetivação das respectivas normas $[\ldots]$.

Neste sentido, a norma penal estaria sendo utilizada com nítida função diplomática. Sobre o impacto da norma de direito penal na esfera política, destaca Betiol (2003, p. 35) que -[...] o direito penal, como ciência jurídica, passa para o segundo plano, especialmente se por ciência jurídica se entender a elaboração de um determinado complexo legislativo vigente, mas não se pode negar que qualquer complexo legislativo penal é a expressão de um dado ambiente político.

Portanto, a confecção da norma penal partindo de sua característica política deve ser compreendida a partir do cenário vivenciado pelo país no momento de sua elaboração. Neste sentido, o país fez com o crime do trabalho escravo, o mesmo que fez com a Lei Feijó, promovendo a criação de uma lei simbólica, eficaz no plano político e ineficaz como instrumento de combate seja por sua ineficácia ou supereficácia seletiva. O -sloganll do terror é empregado como instrumento político para cumprir a pressão externa e satisfazer o efeito midiático interno, maculando a aplicação da norma seja dentro da impunidade e da punição.

Assim, quando surge uma lei que é inaplicável surge a clássica expressão -lei para inglês verll. Essa definição surgiu pela primeira vez com a Lei Feijôn ${ }^{7}$ que previa a proibição do tráfico atlântico de escravos no Brasil. A lei foi criada em um contexto econômico internacional capitalista em formação, haja vista que o capitalismo inglês

necessitava de um mercado de consumo.

\footnotetext{
${ }^{7}$ Promulgada em 7 de novembro de 1831, a primeira lei de proibição do tráfico Atlântico de escravos para o Brasil é origem de uma das expressões mais populares no país, sempre utilizada quando se deseja fazer referência, sobretudo, a dispositivos legais pouco ou nada efetivos: -lei para inglês verll. Fruto das pressões exercidas pelo governo britânico, interessado na extinção do comércio negreiro, a lei Feijó foi praticamente ignorada por traficantes escravista, e mesmo pelo Estado, até que a lei Eusébio de Queiroz, promulgada em 1850, determinou o que seria um ponto final na importação de braços africanos para terras brasileiras. Ao contrário do que se sustentou durante muito tempo, a lei de 1831 não serviu apenas para distrair os -olhosll ingleses (COTA, 2015, p. 65)
} 
Desta maneira, a solução dos capitalistas foi pregar o discurso libertário e combater a escravidão colonial, não para salvar os homens, nem pela dignidade do escravo, mas porque o modelo escravocrata era incompatível com o modo capitalista.

Durante essa época a economia brasileira dependia da escravidão, desta maneira, como resposta econômica criou uma lei formal para acalmar os ingleses e com eles continuar comercializando, sendo uma lei materialmente inaplicável no ordenamento escravocrata brasileiro, contudo, eficaz no plano diplomático e econômico.

O crime da exploração do trabalho escravo, por sua ampla redação acabou ampliando os tipos em demasia. Assim, quando o direito tenta punir de forma demasiada aplicando o terror, quando a legislação tenta defender tanto um direito, acaba muitas vezes não protegendo qualquer direito, gerando num primeiro lado da moeda uma eficácia invertida deixando a norma sem punição. Assim, quando tudo passa a ser crime, a conclusão que se chega é que nada acaba sendo crime. Quando tudo vira trabalho escravo, nada é crime de trabalho escravo.

O outro lado da moeda se manifesta pela supereficácia, ou seja, pelo emprego da analogia nas expressões complexas tenta-se afirmar como certo e definido aquilo que é indefinido e obscuro. O tipo descrito na norma não é simples e claro, causando insegurança na aplicação, seja pela ineficácia ou pela supereficácia. Destaca BECCARIA (2002, p. 102) Desejais prevenir os crimes? Fazei leis simples e claras; [...]\|

A política penal do terror fere a ciência criminológica substituindo ela pela política, esta relação -[...] conduz não só a negação do direito penal como ciência política, mas também a uma forma pura e simples de terror penal. (BETIOL, 2003, p.

36)\|. Assim, dentro deste -terror penall foi ampliado o tipo penal da exploração do trabalho escravo. Nesta relação do combate a escravidão, tutelando direitos humanos ${ }^{8}$, o emprego do poder punitivo traz suas dúvidas.

\footnotetext{
${ }^{8}$ A irrupção dos direitos humanos no discurso jurídico-penal constituiu o mais importante e complexo fenômenos de sua histórica contemporânea. Se, por um lado, tal irrupção contribui para o programa de desterritorialização normativa, funcional perante o empreendimento econômico e político que se esconde atrás da expressão -Globalizaçãoll, levando por vezes à produção discursiva de duvidosos universais (por exemplo, no confronto com culturas jurídicas islâmicas), por outro lado represente inquestionável reforço no delineamento de padrões mínimos de contenção e limitação do poder punitivo. (ZAFARRONI, BATISTA, ALAGIA e SLOKAR, 2003, P. 339)
} 
Identifica-se dentro do discurso dos direitos humanos a justificativa para a aplicação do -terror penall e a função extremamente punitiva do Estado. Contudo, na análise da própria função da pena e na severidade ampliada pela participação política dentro do direito penal -[...] O produto final desta competitividade costuma resultar em leis penais absurdas, disputas por projetos mais repressivos, sentenças exemplarizantes e uma opinião pública confundida e desinformadas.\| (ZAFFARONI, BATISTA, ALAGIA e SLOKAR, 2003, P. 61).

Assim é possível afirmar que o crime não representa um efetivo instrumento de combate ao trabalho escravo, mas sim um disfarce, uma legislação simbólica, que num primeiro momento é ineficaz, como a Lei Feijó em 1831, servindo como uma -lei para ingleses verem\| e brasileiros descumprirem. Dentro do -terror $\|$ criminal os -...-$]$ discursos políticos, pode dirigir-se exatamente ao encobrimento da insuficiente força normativa dos respectivos institutos jurídicos ou mesmo a prejudicá-la. [...] (NEVES, 2005, 17)\|.

Num segundo momento totalmente oposto a ineficácia surge a supereficácia seletiva promovendo através de sentenças exemplarizantes a destruição de outros direitos fundamentais que garantem a aplicação da pena dentro da estrita legalidade e da certeza do direito. Como destaca (ZAFFARONI, 2003) o terror criminal, o efeito midiático confunde o sistema penal por decisões que tentam gerar eficácia no discurso jurídico penal a qualquer custo.

Para compreender esta problemática trazida com a norma simbólica, o estudo da sociologia e da criminologia na Teoria da Anomia Emile Durkheim e Robert King Merton, promove a tentativa de afastar o modelo médico patológico da criminologia.

\footnotetext{
Em termos gerais, para Durkheim, a lei serve, na sociedade moderna, para regulamentar as ações dos diferentes grupos que dela fazem parte. Quando essa regulação é inadequada ou incipiente, forma-se uma situação de anomia. [...] Já para Merton, verifica-se na sociedade contemporâneas uma mudança muito rápida dos valores sociais vigentes e não há tempo para que se sedimente sua substituição por outros alternativos. (Neste interregno, o indivíduo fica sem referência das regras, a obedecer, constituindo-se uma situação anômica ARAUJO, 2010, p. 58).
}

Procura-se, portanto, compreender que o crime não é uma doença, uma patologia, uma exceção. Desta maneira, a teoria da anomia integra o pensamento e propósito funcionalista promovendo a integração entre os valores de convívio em sociedade não excluindo o indivíduo que pratica o delito, reconhecendo como uma peça dentro da sociedade. 
A importância do debate entre a legislação simbólica e a Criminologia se torna prudente, especialmente para o reconhecimento dos motivos de criminalidade e criminalização além da lei, mas pelas circunstâncias que motivam a existência e a prática do delito, analisando desta maneira o crime, o infrator, a vítima e os motivos associados a existência do delito e do controle social. (ARAUJO, 2010).

Alessandro Baratta ${ }^{9}(2004)$ destaca que a Anomia não busca nos fatores biológicos, antropológicos e naturais como o clima e a raça razões para a existência dos desvios, para o autor trata-se de um fenômeno normal da estrutura da sociedade. Desta maneira, quando são superados os limites impostos, acompanhados por um modelo desorganizado, em que o sistema de normas de conduta perde o valor, visualiza-se o comportamento desviado como um fator necessário e útil para o equilíbrio e desenvolvimento. Desta forma, Durkheim não via o delinquente como uma espécie de parasita, um corpo estranho, mas como um agente regulador da vida em sociedade.

Dentro de sua obra -0 suicídioll, Durkheim apresenta uma análise da anomia que representaria um —estado de desregramentoll, na qual não se identifica a presença de um ideal coletivo capaz de limitar a atividade indivíduos, mas a presença de -espaços anômicos $\|$ os quais presenciam na perda de referência normativas o enfraquecimento da solidariedade e a perda destes pilares. (BARBOSA, 2013).

Pela visão Hobbes (2007) o homem é por natureza um ser que vive em torno da discórdia, apontando como principais causas a competição, a desconfiança e a reputação. Dentro da primeira causa, manifesta-se o lucro fato essencial para a violência típica do sistema capitalista que provoca a prática do crime do trabalho escravo.

\footnotetext{
9 La teoría estructural-funcionalista de la anomia y de ln criminalidad afirma: 11 Las causas de la desviación no deben buscarse ni em factores bioantropológicos y naturales (clima, raza), ni en uma situación pztológica de la estructura social. 21 La desviación es un fenómeno normal de toda estrutura social. 31 Sólo cuando se hayan sobrepasado ciertos límites, el fenómeno de la desviación es negativo para la existencia) el desarrollo de la estructura social, si se acompaña de un estado de desorganización, en el cual todo el sistema de reglas dc conducta pterde valor, mientras no se haya afirmado aún nuevo sistema (es ésta la situación de "anomia"). Viceversa, dentro de sus límites funcionales, el comportamiento desviado es un factor necesario y útil del equilibrio y del desarrollo sociocultural [...]Durkheim no veía ya al delincuente como "ser radicalmente antisocial, como una especie de elemento parasitario, de cuerpo extraño e inasimilable, introducido en el seno de la sociedad", sino más bien como "um agente regulador de la vida social". BARATTA (2004, p.56-7)
} 
A desconfiança encontra-se atrelada a própria condição violenta de procurar ser antes um -senhor do Engenholl do que um escravo. Acerca da reputação ela se encontra naturalmente inserida pela glória de uma sociedade marcada pela luta de classes.

Portanto, quando a norma penal ampliou o -terrorl penal utilizou a legislação simbólica como um instrumento para cumprir obrigações internacionais e controlar o efeito midiático. Contudo, criou espaços de anomias daqueles que não visualizam a prática do crime da maneira como está descrito na norma.

Percebe-se que a lei penal possui eficácia aparente em torno da diplomacia, contudo, gera a eficácia invertida no plano material fomentando a criação de leis próprias de mercado paralelo que aplicam a teoria econômica marxista da -Mais Valiall explorando o trabalho escravo, sem encontrar representatividade na norma penal proibitiva.

Dentro deste cenário simbólico, acaba surgindo através de sentenças exemplarizantes a -superficáciall ou a -eficácia a qualquer custoll. Assim, dentro desta simbologia surge outro extremo que é marcado pela interpretação analógica, promovendo a aplicação da lei penal como sendo perfeita, embora, como visto ao longo do trabalho sua definição é extremamente contraditória e não unânime.

Desta maneira, a imprecisão do tipo penal gera o extremo da ineficácia de um lado e do outro a supereficácia. Este cenário causa insegurança jurídica por uma norma que cumpriu apenas a sua função midiática e política. Acerca do emprego de sentenças exemplarizantes com o emprego da analogia destaca FRAGOSO que no Código Penal da Alemanha Nazista -[...] permitia o emprego da analogia, sempre que o fato não estivesse expressamente previsto e merecesse uma punição

-segundo os princípios fundamentais do direito penall e o -são sentimento do provol-.

Durante o regime totalitário nazista as expressões vagas como o -são sentimento do povoll, determinaram e justificaram a prática do terror e a violação de diversos direitos humanos pela analogia. Desta maneira, embora o discurso seja defensor dos direitos humanos com o uso de sentenças exemplarizantes, o emprego da eficácia -a qualquer custoll, traz um grande risco dentro de expressões complexas e de difícil definição.

O poder legislativo reflete na simbologia da escravidão a sua imprecisão, portanto, como destaca ZAFFARONI, BATISTA, ALAGIA E SLOKAR (2003, p. 203) não é possível que -[...] a doutrina, a jurisprudência ou o costume sejam capazes de habilitar o poder punitivo. [...].॥ Desta maneira, os Tribunais devem exercem a sua função judicial e não podem promover a ampliação de tipos penais a custo da eficácia, neste sentido, como destaca o autor acima 
-[...] Os tribunais não são fonte de produção da legislação penal nem a jurisprudência é fonte de seu conhecimento.[...].

O Crime de Exploração do Trabalho Escravo, assim como a grande maioria dos crimes acaba sendo praticados em virtude -[...] a fetichização da mercadoria, da reificação do indivíduo, e do individualismo burguês que reduzem a condição humana a uma simples condição mercadológica.(CASTRO, 2007, p. 129).\| O capitalismo é um instrumento de incentivo para o homem revelar seus desejos naturais individualistas e egoístas.

O modelo capitalismo agressivo dita leis de um mercado paralelo que destroem a busca pela vida em sociedade. Surgem -leisll de um mercado -ilegall pela violência e a consequente prática do crime, o qual sobrevive pelo -[...] complexo de miserabilização das massas exploradas pelo grande capital, é a principal causa do aumento da violência individual (CASTRO, 2007, p. 137)川.

Desta maneira, o capitalismo em sua construção egoísta é o motivo pelo qual o sujeito pratica o crime de exploração de mão de obra escrava, bem como a razão pela qual existe o excedente de classes exploradas que por sua miserabilidade criam um -novoll exército de mão de obra escrava.

A criminologia burguesa, encarregada de legitimar ideologicamente a ação concreta
do sistema penal, desde Lombroso vinha insistindo em ter como objeto de análise o
homem criminoso, como um ser anti-social, que se nega à venda de sua força de
trabalho ao capital, preferindo, ao contrário, muitas vezes, viver da expropriação
violenta de bens, seja da burguesia, seja do próprio proletariado. Logo, toda a
produção criminológica positivista ou etiológica vinha girando em torno à procura
das causas da criminalidade. O chamado -labeling approachll, ou teoria da reação
social, acabou por questionar este estado de coisas a partir de 3 eixos básicos:
a) a relatividade do crime; b) as cifras ocultas da criminalidade e c) o crime do
colarinho branco. Com isto, ocorria uma inversão do objeto de investigação das
causas da criminalidade para as causas da criminalização. (CASTRO,
2007, p. 138)

Dentro do eixo básico das cifras ocultas da criminalidade, tem a causa da criminalização e criminalidade o alto lucro e a forma de competitividade dentro de um sistema de difícil acesso ao capital que já se encontra concentrado nas mãos de uma pequena minoria.

Dentro deste jogo simbólico, econômico e político, a norma penal é utilizada como moeda, revelando dois lados opostos em sua aplicação: a ineficácia e a supereficácia seletiva marcada pelo emprego da analogia. O problema surge pela dificuldade em conceituar de maneira fechada o que seria a escravidão contemporânea e admitir a sua relação intrínseca com a exploração do capital. 


\section{CONSIDERAÇÕES FINAIS}

A escravidão como pode ser observada ao longo do estudo não é uma passagem histórica que relembra a época do Brasil colônia. Os relatórios fornecidos pela OIT, bem como os dados divulgados pelo Ministério Público do Trabalho permitem a conclusão que o trabalho forçado é um tema presente, o que reflete a importância do debate.

Dentro deste cenário o Brasil assumiu diversos compromissos internacionais de combate à escravidão contemporânea. Diante disso, precisa apresentar dados que demonstrem que o combate do trabalho escravo.

A lei 10.803/2003 que alterou o artigo 149 do Código Penal foi utilizado como um -álibill político internacional, a qual na aplicação do - terrorll penal, na extensão da punição procurava o respaldo de ser considerado um país que combate a escravidão, controlando o efeito midiático interno.

Contudo, assim como feito com a Lei Feijó em 1831 foi criada uma -Lei para inglês verll, formalmente eficaz dentro da diplomacia, mas materialmente ineficaz como instrumento de combate a escravidão.

A existência desta relação revela a problemática da escravidão contemporânea e os disfarces que são utilizados dentro do discurso dos direitos fundamentais. A ampliação da norma e sua ineficácia penal revelam a ausência de uma definição unânime sobre o que é a escravidão contemporânea, criando espaços paralelos de ilegais, de leis de mercado que cultivam o modo de exploração do lucro a qualquer custo.

A ampliação da escravidão no crime trouxe efeitos ineficazes na punição, os quais pela Teoria da Anomia da criminologia torna possível a afirmação da relação intrínseca e umbilical do Capitalista agressivo com a escravidão contemporânea.

Do lado oposto da ineficácia, surge a supereficácia seletiva que acaba pregando a punição a qualquer custo. Dentro dela, nasce a insegurança pelo emprego da analogia como solução.

O trabalho representa um estado de pesquisa em desenvolvimento, portanto, o artigo não procura apresentar afirmações peremptórias, mas fomentar a discussão da legislação simbólica e seus efeitos que envolvem dois lados da mesma moeda: ineficácia ou supereficácia seletiva. 


\section{REFERÊNCIAS}

ARAUJO, Fernanda Carolina de. A teoria Criminológica do labelling approach e as medidas socioeducativa. Dissertação (Mestrado), Faculdade de Direito da Universidade de São Paulo. São Paulo, 2013.

BARATTA, Alessandro. Criminología crítica y crítica del derecho penal: introducción a la sociología jurídico penal.- 11 ed. P reimp.- Buenos Aires: Siglo XXI Editores Argentina, 2004.

BARBSOSA, Gilmara Maria de Oliveira. Anomia, Direito e Pós-Modernidade. Revista do Instituto de Direito Brasileiro. Lisboa, n.9, p. 9043-9081, 2013.

BECCARIA, Cesare. Dos delitos e das Penas. Trad. Torrieri Guimarães. São Paulo: Martin Claret, 2003.

BETIOL, Giuseppe. O Problema Penal. Tradução e notas de Ricardo Rodrigues Gama Campinas: LZN Editora, 2003.

BITENCOURT, Cezar Roberto. Tratado de Direito Penal: Parte especial, vol. 2, 6 ed. Ver. E atual. - São Paulo: Saraiva, 2007.

BOUCHER, Geoff. Marxismo. Tradução de Noeli Correia de Melo Sobrinho -Pedrópolis, RJ - VOZES, 2015.

BRASIL. Decreto n. 41.721, de 25 de Junho de 1957. Promulga as Convenções Internacional do Trabalho de $n^{o}$ 11,12,13,14,19,26,29,81,88,89,95,99,100 e 101 firmadas pelos Brasil e outros países em sessões da Conferência Geral da Organização Internacional do Trabalho. Convenção $n^{o} 29$ - Convenção Internacional sobre o Trabalho Forçado. Disponível em: < http://www.planalto.gov.br/ccivil_03/decreto/Antigos/D41721.htm> acesso em: 29 abr. 2015.

CASTRO, Matheus Felipe de. A criminologia da luta de classes. Discursos Sediciosos: crime, direito e sociedade. Editora Revan, v. 15/16, p. 121-147, Rio de Janeiro: 2007.

COTA, Luiz Gustavo Santos. Não só "para inglês ver\|: justiça, escravidão e abolicionismo em Minas Gerais. Dissertação (Mestrado em História). Juiz de Fora: Universidade Federal de Juiz de Fora, 2011. Disponível em< http://www.ifch.unicamp.br/ojs/index.php/rhs/article/viewFile/912/683> Acesso em 04 ago. 2015

FRAGOSO, Heleno Cláudio. Lições de Direito Penal: Parte Geral - Ed. e ver. Por Fernando Fragoso - Rio de Janeiro: Forense, 2006

, Cláudio Heleno. Observações sobre o Princípio da Reserva Legal. disponível em: <http://www.fragoso.com.br/eng/arq_pdf/heleno_artigos/arquivo11.pdf> acesso em 30 mar. 2016.

GORENDER, Jacob. O Escravismo Colonial. $4^{\circ}$ Ed. São Paulo; Editora Fundação Pserseu Abramo, 2010. 
HOBBES, Thomas Hobbes; O Leviatã. Org. Richard Tuck ; trad. João Paulo Monteiro, Maria Beatriz Nizza da Silva, Claudia Berliner ; rev. Eunice Ostrensky. - São Paulo: Martins Fontes, 2003.

LÊNIN, Vladimir Ilitch. Como iludir o povo - Coleção Bases 11. Global Editora. São Paulo/SP. 1979

LÉVI - STRAUSS, Claude. Raça e História., - Titulo Original RACE OT HISTOIRE UNESCO - 1952 - Trad. de Inacia Canelas - LISBOA, Editorial Presença (1960)

MARX, Karl. O Capital: supervisão editorial Jair Lot Vieira: Tad. e cond. Gabriel Deville Bauru, SP EDI-PRO, 1998.

NEVES, Marcelo. A Força Simbólica dos Direitos Humanos. Revista Eletrônica de Direito do Estado, Salvador, n. 4, p. 1 -35, 2005.

ORGANIZAÇÃO INTERNACIONAL DO TRABALHO (OIT). Trabalho escravo no Brasil do Século XXI .1 $1^{\circ}$ Edição- 2006 Coordenação do estudo: Leonardo Sakamoto disponível em<http://www.oitbrasil.org.br/sites/default/files/topic/forced_labour/pub/trabalho_esc ravo_no_brasil_do_\%20seculo_\%20xxi_315.pdf> Acesso em 21 abr. 2015

POULANTZAS, Nicos. O estado, o Poder, o Socialismo - São Paulo: Paz e Terra, 2000.

ROCHA, Graziella. Tráfico de Pessoas e Trabalho Escravo Contemporâneo na Perspectiva dos Tratados Internacionais e da Legislação Nacional. Revista Seção Judiciária do Rio de Janeiro. Rio de Janeiro, n.37, p. 29-51, 2013.

VIANA, Marcio Túlio. Trabalho Escravo e "Lista Suja": Um modo original de se remover uma mancha. Revista do Tribunal Regional do Trabalho da $3^{\text {a }}$ Região, Belo Horizonte, v.44, n.74, p.189-215, 2006

WILLIAMS, Eric. Capitalismo e Escravidão: tradução de Denise Bottmann: prefácio Rafael de Bivar Marquese, São Paulo: Companhia das Letes, 2012.

ZAFARRONI, BATISTA, ALAGIA e SLOKAR. E. Raul. Direito Penal Brasileiro: primeiro volume - Teoria Geral do Direito Penal. Rio de Janeiro: Revan, 2003. 